\title{
PENGARUH CITRA MEREK TERHADAP KEPUTUSAN KONSUMEN MEMBELI MOBIL DAIHATSU XENIA PADA PT. MAKASSAR RAYA MOTOR CABANG PALU
}

\author{
Inten Suweno Syamdi BS \\ Maskuri Sutomo \\ Farid \\ Program Studi S1 Manajemen, Fakultas Ekonomi, Universitas Tadulako \\ Email: intensyamdi48@gmail.com, Maskuri.sutomo@yahoo.com, Farid4567@yahoo.com
}

\begin{abstract}
The purpose of this research is to find out and analyze the influence of brand image on consumer's who buy Daihatsu Xenia cars at PT Makassar Raya Motor Branch Palu. The variables of this study are brand image which consists of the advantages of brand association, brand association strength and brand association uniqueness. While the dependent variable of Consumer's decision. The type of this research is descriptive causal. The sampling technique used purposive sampling with a sample size of 60 people. The analytical tool used is multiple linear regression analysis. The results of this study indicate that the variable brand image which consists of the advantages of brand association, the strength of brand association and the uniqueness of brand association simultaneously have a significant effect on consumer's decisions to buy a car Daihatsu Xenia in PT Makassar Raya Branch Motor of Palu. From the test results partially found that the variable of brand image which consists of the advantages of brand association, the strength of brand association and the uniqueness of brand association significantly influence consumer's decisions.
\end{abstract}

Keywords: brand image, consumer's decision

\section{Abstrak}

Tujuan penelitian ini adalah untuk mengetahui dan menganalisis pengaruh citra merek pada konsumen yang membeli mobil Daihatsu Xenia di PT Makassar Raya Motor Cabang Palu. Variabel penelitian ini adalah citra merek yang terdiri dari keunggulan asosiasi merek, kekuatan asosiasi merek dan keunikan asosiasi merek. sedangkan variabel dependen keputusan Konsumen. Jenis penelitian ini yaitu penelitian deskriptif kausal. Teknik penarikan sampel menggunakan purposive sampling dengan jumlah sampel 60 orang. Alat analisis yang digunakan adalah analisis regresi linear berganda. Hasil penelitian ini menunjukkan bahwa variabel citra merek yang terdiri dari keunggulan asosiasi merek, kekuatan asosiasi merek dan keunikan asosiasi merek secara simultan berpengaruh signifikan terhadap keputusan konsumen membeli mobil Daihatsu Xenia pada PT Makassar Raya Motor Cabang Palu. Dari hasil pengujian secara persial ditemukan bahwa variabel citra merek yang terdiri dari Keunggulan Asosiasi Merek, Kekuatan asosiasi merek dan Keunikan asosiasi merek berpengaruh signifikan terhadap keputusan konsumen.

Kata Kunci: Citra Merek, Keputusan Konsumen.

\section{PENDAHULUAN}

Kebutuhan akan alat transportasi dewasa ini telah menjadi kebutuhan primer. Sebagian besar orang lebih memilih untuk menggunakan alat transportasi pribadi dibandingkan dengan alat transportasi umum. Salah satu industri yang tumbuh pesat sampai saat ini adalah industri otomotif. Diantara berbagai jenis mobil, terdapat satu jenis yang paling banyak diminati konsumen, yakni kendaraan serba guna (Multi Purpose Vehicle/MPV). Mobil jenis MPV adalah mobil dengan kapasitas muat yang banyak baik penumpang maupun barang. Adapun jenis MPV dari berbagai merek membanjiri pasar mobil nasional diantaranya Toyota (Innova dan Avanza), Daihatsu (Xenia),Honda (Odyssey dan Stream), Suzuki (APV) dan lain-lain.

Adapun perusahaan distributor mobil di Kota Palu antara lain: PT. Makassar Raya Motor ( Daihatsu ), PT. Hasrat Abadi (Toyota), PT. Hadji Kalla (Toyota), PT. Bosowa Berlian Motor (Mitsubishi) dan PT. Patrako Motor Abadi (Suzuki).

PT. Makassar Raya Motor cabang palu merupakan Diler resmi satu-satunya kendaraan bermotor merek Daihatsu, yang daerah pemasarannya meliputi Sulawesi Tengah dan sekitarnya. PT. Makassar Raya Motor Cabang Palu menerapkan standar Daihatsu dalam beroperasi meliputi penjualan, servis dan penyediaan suku cadang atau yang lazim disebut 3S (Sales, Service dan Spare Parts). Tipe mobil yang di tawarkan adalah 
Xenia, Granmax, Luxio, Terios, Sirion, dan Ayla.

Data penjualan mobil Daihatsu pada PT. Makassar Raya Motor Palu dari tahun 2012-2015 cenderung mengalami peningkatan. Selanjutnya penjualan pada tahun 2016 mengalami penurunan. Adapun data penjualan mobil PT. Makassar Raya Motor cabang Palu dari tahun 2012-2016 adalah sebagai berikut pada tabel 1:

Tabel 1

Data Penjualan Mobil PT. Makassar Raya Motor Cabang Palu (2012-2016)

\begin{tabular}{|c|c|c|c|c|c|c|c|}
\hline \multirow[t]{2}{*}{ NO } & \multirow[t]{2}{*}{ Type } & \multicolumn{6}{|c|}{ Penjualan / Tahun } \\
\hline & & 2012 & 2013 & 2014 & 2015 & 2016 & Jumlah \\
\hline 1 & Xenia & 92 & 111 & 180 & 185 & 96 & 664 \\
\hline 2 & Grandmax & 102 & 112 & 128 & 156 & 160 & 658 \\
\hline 3 & Luxio & 33 & 34 & 34 & 21 & 8 & 130 \\
\hline 4 & Terios & 87 & 40 & 41 & 25 & 18 & 211 \\
\hline 5 & Sirion & 26 & 24 & 25 & 18 & 18 & 111 \\
\hline 6 & Ayla / Sigra & - & - & 100 & 125 & 100 & 325 \\
\hline \multicolumn{2}{|c|}{ Total } & 340 & 321 & 508 & 536 & 394 & 2.099 \\
\hline
\end{tabular}

Sumber: Data Penjualan Mobil PT. Makassar Raya Motor Cabang Palu

Berdasarkan data diatas,Penjualan Daihatsu Xenia terus mengalami peningkatan sepanjang 2012 hingga 2015. Penurunan penjualan terjadi pada tahun 2016 yang hanya sebanyak 96 unit.Namun, selama lima tahun terakhir Daihatsu Xenia merupakan mobil keluarga dengan tingkat penjualan tertinggihingga mencapai 664 unit

Mobil Xenia menjadi kendaraan kelas MPV (Multi Purpose Vehicle), yang banyak diminati dan digunakan sebagai car family (Mobil Keluarga) di Kota Palu. Penampilan interior maupun eksterior yang mewah dan menarik serta mesin yang kuat menambah kehandalan kendaraan tersebut. Desain stylish dan juga sporty dianggap bisa merefresikan karakter pemiliknya yang dinamis moderen Dari segi harga, kendaraan ini juga memberikan harga yang cukup terjangkau. Kemudian dari segi keselamatan, mobil ini telah di lengkapi dengan perangkat keselamatan standar seperti kantong udara buat pengemudi dan penumpang serta rem ABS (Anty Lock Bracking System).

Namun produk mobil jenis MPV, Toyota Avanza menjadi pesaing terkuat dari Daihatsu Xenia. Konsumen tidak hanya memperhatikan nilai utama produk, tetapi juga memperhatikan kualitas serta mempertimbangkan citra merek, harga dan kualitas pelayanan yang diberikan oleh perusahaan. Memiliki citra merek yang kuat merupakan suatu keharusan bagi setiap perusahaan khususnya yang ada di wilayah Kota Palu. Karena citra merek merupakan aset perusahaan yang sangat berharga. Dibutuhkan kerja keras dan waktu yang cukup lama untuk membagun reputasi dan citra merek.

Berdasarkan uraian diatas, maka penelitian ini bertujuan untuk menganalisis karateristik citra merek ( keunggulan asosiasi merek, kekuatan asosiasi merek dan keunikan asosiasi merek) terhadap keputusan konsumen membeli mobil Daihatsu Xenia pada PT. Makassar Raya Motor Cabang Palu.

\section{KAJIAN LITERATURE DAN PENGEMBANGAN HIPOTESIS}

America Marketing Association (AMA) dalam Kotler dan Keller (2009:258) mendefenisikan merek sebagai nama, istilah, lambang, atau desain, atau kombinasinya, yang dimaksudkan untuk mengidentifikasikan mereka dari para pesaing. Maka merek adalah produk atau jasa yang dimensinya mendiferensiasikan merek tersebut dengan beberapa cara dari produk atau jasa lainnya yang dirancang untuk memuaskan kebutuhan yang sama. Suyanto (2008:103), Citra Merek dapat dijelaskan sebagai evaluasi konsumen terhadap suatu merek secara keseluruhan. Hal ini penting karena seringkali membentuk dasar dari actions (perbuatan) dan behavior (perilaku) konsumen terhadap suatu merek (pemilihan merek).

Citra merek yang terdiri dari citra perusahaan, citra pemakai, citra produk dan pengetahuan produk secara 
simultan berpengaruh signifikan terhadap keputusan pembelian produk (Desi,2017)

Menurut Kotler dan Keller (2009:259) Citra Merek adalah gambaran mental atau konsep tentang sesuatu. Faktor-faktor pendukung terbentuknya citra merek dalam keterkaitannya dalam asosiasi merek (Kotler dan Keller 2009:167) yaitu, terdiri dari:

\section{Keunggulan Asosiasi Merek}

Salah satu faktor pembentuk citra merek adalah keunggulan produk, dimana produk tersebut unggul dalam persaingan. Karena keunggulan kualitas (model dan kenyamanan) dan cirri khas itulah yang menyebabkan suatu produk mempynyai daya tarik tersendi bagi konsumen.

\section{Kekuata Asosiasi Merek}

Membangun kepopuleran merek dengan strategi komunikasi melalui periklanan. Setiap merek yang berharga mempunyai jiwa, suatu kepribadian khusus adalah kewajiban mendasar bagi pemilik merek untuk dapat mengungkapkan, mensosialisasikan jiwa/kepribadian tersebut dalam satu bentuk iklan ataupun bentuk kegiatan promosi dan pemasaran lainnya.

\section{Keunikan Asosiasi Merek}

Asosiasi terhadap suatu merek mau tidak mau harus berbagi dengan merek-merk lain. Oleh karena itu, harus diciptakan keunggulan bersaing yang dapat dijadikan alasan bagi konsumen untuk memilih suatu merek tertentu, dengan memposisikan merek lebih mengarah kepada pengalaman atau keuntungan dari citra produk tersebut dari perbedaan yang ada, baik dari produk, pelayanan, personil, dan saluran yang dihrapkan memberikan perbedaan dari pesaingnya.

Nickels (2010:106) Proses pengambilan keputusan konsumen adalah suatu prose yang merupakan bauran antara adanya kebutuhan terhadap suatu produk dengan adanya rangsangan dari luar dengan memengaruhi konsumen dalam mengambil keputusan untuk membeli suatu produk. Salah satu keputusan yang penting diambil konsumen dan harus mendapat perhatian yang besar dari para pemasar adalah keputusan pembelian konsumen. Menurut Kotler dan Keller (2009:184) untuk sampai kepada keputusan pembelian konsumen akan melewati 5 tahap yaitu:

\section{Gambar 1 \\ Proses Pengambilan Keputusan Pembelian}

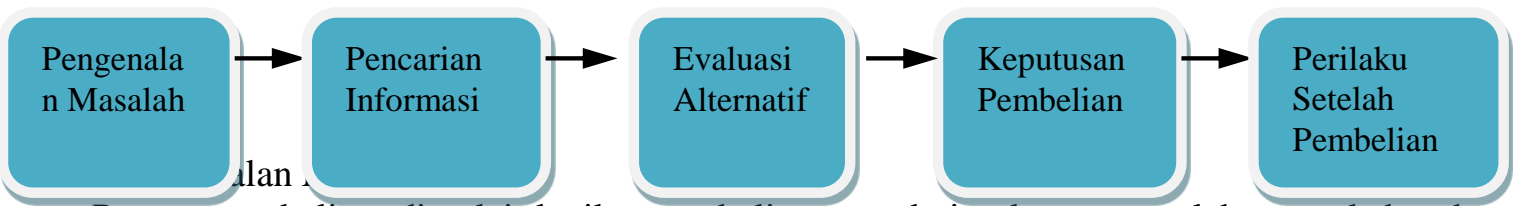

Proses pembelian dimulai ketika pembeli menyadari adanya masalah atau kebutuhan. Pembeli merasakan perbedaan antara keadaan aktualnya dengan keadaanyang diingankannya. Kebutuhan tersebut dapat dipicu oleh rangsangan internal seperti lapar dan haus yang bila mencapai titik tertentu akan menjadi sebuah dorongan dan rangsangan eksternal. Misalnya ketika melewati toko kue yang merangsang rasa laparnya.

b. Pencarian Informasi

Setelah tergerak oleh stimulus pemasaran, konsumen berusaha mencari informasi lebih banyak tentang hal yang dikenalinya sebagai kebutuhannya. Konsumen memperoleh info dari sumber pribadi (keluarga, teman, tetangga, dan kenalan), komersial (iklan, tenaga, penjual, pe rantara, dan kemasan), publik (media massa, organisasi pembuat peringkat) dan sumber pengalaman (pengkajian,pemakaian produk).

c. Evaluasi Alternatif

Evaluasi alternatif merupakan tahapan dimana konsumen memperoleh informasi tentang suatu objek dan membuat penilaian akhir. Pada tahap ini konsumen menyempitkan pilihan hingga alternatif yang dipilih berdsasarkan besarnya kesesuaian antara manfaat yang diinginkan dengan yang bisa diberikan oleh pilihan produk yang tersedia.

d. Keputusan Membeli

Keputusan pembeli merupakan tahapan dimana konsumen telah memiliki pilihan dan siap melakukan transaksi pembelian atau pertukaran antara uang atau janji untuk membayar dengan hak kepemilikan atau penggunaan suatu benda. 
e. Perilaku Setelah Pembelian

Perilaku setelah pembelian merupakan tahapan dimana konsumen akan mengalami dua kemungkinan yaitu kepuasan dan ketidakpuasan terhadap pilihan yang diambilnya.

\title{
Kerangka Pemikiran
}

\section{Gambar.2}

\author{
Kerangka Pemikiran
}

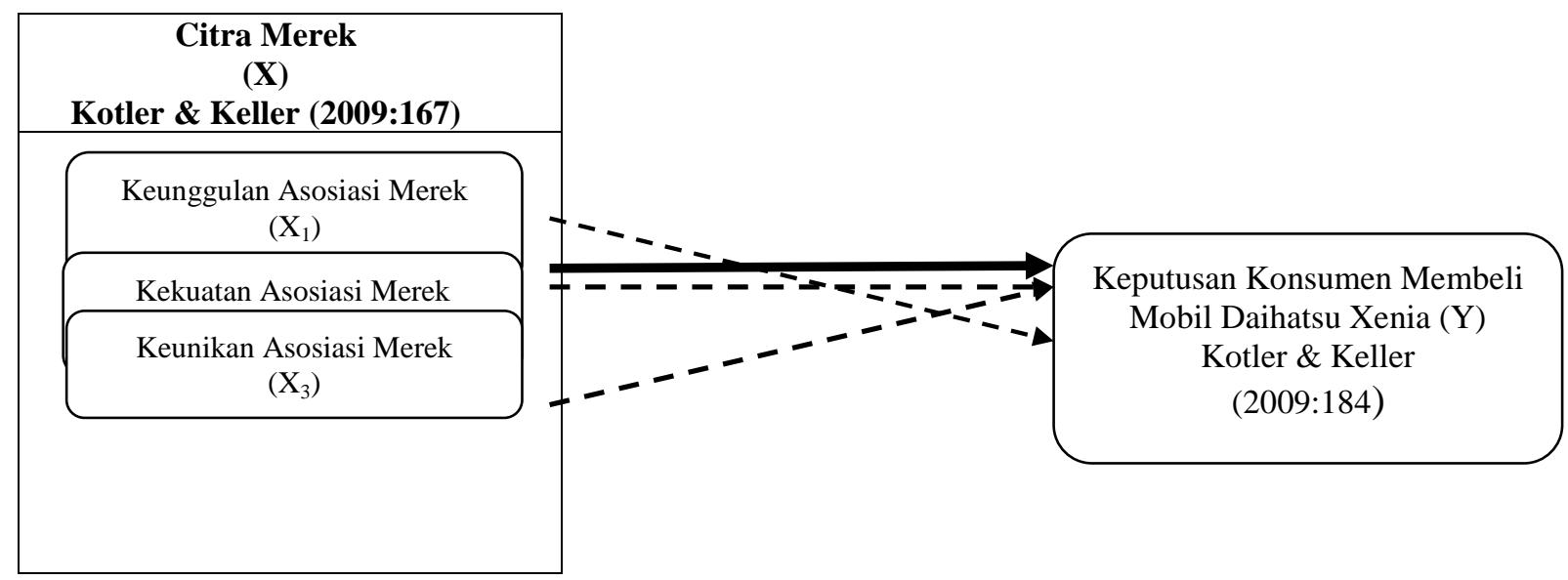

Keterangan:

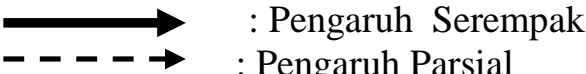

: Pengaruh Parsial

\section{Hipotesis}

Berdasarkan uaraian pada kerangka pemikiran diatas, maka hipotesis yang diajukan dalam penelitian ini adalah:

1. Citra Merek yang terdiri dari Keunggulan Asosiasi Merek, Kekuatan Asosiasi Merek dan Keunikan Asosiasi Merek berpengaruh signifikan secara serempak terhadap keputusan konsumen membeli mobil Daihatsu Xenia pada PT. Makassar Raya Motor Cabang Palu.

2. Keunggulan Asosiasi Merek berpengaruh signifikan secara parsial terhadap keputusan konsumen membeli mobil Daihatsu Xenia pada PT. Makassar Raya Motor Cabang Palu.

3. Kekuatan Asosiasi Merek berpengaruh signifikan secara parsial terhadap keputusan konsumen membeli mobil Daihatsu Xenia pada PT. Makassar Raya Motor Cabang Palu.

4. Keunikan Asosiasi Merek dapat berpengaruh signifikan secara parsial terhadap keputusan konsumen membeli mobil Daihatsu Xenia pada PT. Makassar Raya Motor cabang Palu.

\section{METODE PENELITIAN}

Jenis penilitian ini adalah penelitian deskriptif dan kausal, menurut (Malhotra,2006:291) Penelitian kausal bertujuan untuk mengetahui hubungan antara variabel penelitian melalui penguji hipotesis yang memakai perhitungan statistik. Tipe penelitian deskriptif dilakukan untuk memperoleh gambaran tentang keputusan konsumen membeli Mobil Daihatsu Xenia di kota Palu, sehingga dalam penelitianya terdapat variabel independen (Citra Merek) terhadap variabel dependen (Keputusan Konsumen). Subjek penelitian ini adalah konsumen Daihatsu Xenia. Penilitian ini dilakukan di PT. Makassar Raya Motor Cabang Palu.

Berdasarkan pertimbangan tersebut peneliti menetapkan jumlah sampel dengan ketentuan $15 \times 4$ variabel, yaitu 60 responden. Metode pengambilan sampel yang digunakan adalah non probability sampling dengan teknik Iccidental Sampling yaitu teknik penentuan sampel berdasarkan kebetulan, yaitu siapa saja yang kebetulan bertemu dengan peneliti dapat digunakan sebagai sampel, bila dipandang orang yang kebetulan ditemui itu cocok sebagai sumber data (Sugiyono 2014:85).

Teknik pengumpulan data yang digunakan adalah sebagai berikut (Sugiyono,2014:138): 
1. Pengamatan (Observation), sebagai teknik pengumpulan data mempunyai ciri yang spesifik bila dibandingkan dengan tekinik yang lain. Teknik pengumpulan data dengan observasi digunakan bila, penelitian berkenaan dengan perilaku manusia, proses kerja dan bila responden yang di amati tidak terlalu besar. Pada penelitian ini penelitian mengamati bagaimana fenomena citra merek terhadap keputusan konsumen pada PT. Makassar Raya Motor cabang Palu.

2. Kuesioner (Angket), merupakan teknik pengumpulan data yang dilakukan dengan cara memberikan pertanyaan atau pertanyaan tertulis kepada pengguna mobil Daihatsu Xenia. Kuesioner yang dibuat akan disebarkan dan di isi oleh konsumen yang melakukan keputusan pembelian mobil Daihatsu Xenia pada PT. Makassar Raya Motor, yang mana peneliti sangat mengharapkan kejujuran dari setiap individu dalam pengisian kuesioner tersebu.

3. Wawancara (interview), adalah proses Tanya jawab dalam penelitian yang berlangsung secara lisan dimana dua orang atau lebih bertatap muka mendengarkan secara langsung informasi-informasi atau keterangan-keterangan.

\section{Uji Validitas}

Validitas mempunyai arti sejauh mana ketepatan dan kecermatan suatu alat ukur dalam melakukan fungsi ukurnya, dengan kata lain suatu instrumen penelitian dapat dikatakan mempunyai validitas tinggi apabila alat tersebut menjalankan fungsi ukurnya atau memberikan hasil ukur yang sesuai dengan maksud dilakukan pengukuran tersebut (Sugiyono.2014:121). Syarat minimum untuk memenuhi syarat tersebut adalah jika $r$ > 0,3 .

\section{Uji Realibilitas}

Instrumen penelitian selain valid, juga harus dapat diandalkan (reliable), instrument dapat dikatakan reliabel jika alat tersebut menghasilkan nilai-nilai yang konsisten, dengan demikian instrument ini dapat dipakai dengan aman karena dapat bekerja dengan baik pada waktu yang berbeda dengan kondisi yang berbeda (Sugiyono 2014: 130). Suatu instrumen disebut reliabel apabila alpha croncbach lebih besar dari 0,06.

\section{Uji Normalitas}

Ghozali (2011:161-162) mengemukakan bahwa untuk menguji suatu data berdistribusi normal atau tidak, dapat diketahui dengan menggunakan grafik normal p-plot.

2 Uji Heteroskedastitas

Ghozali (2011:139) mengemukakan bahwa untuk melihat ada tidaknya problem heteroskedastisitas adalah dengan media grafik, apabila tidak ada pola yang jelas, serta titik-titik menyebar di atas dan di bawah angka 0 pada sumbu Y, maka tidak terjadi Heteroskedastisitas.

3. Uji Multikoliniearitas

Uji multikolinearitas dimaksudkan untuk mengetahui apakah variabel independen tidak saling berkorelasi atau tidak terdapat hubungan yang signifikan antara variabel Ghozali (2011:105).

\section{Analisis Regresi Linear Berganda}

Untuk menguji pengaruh variabel citra merek terhadap keputusan konsumen mobil Daihatsu Xenia pada PT. Makassar Raya Cabang Palu maka digunakanalat uji statistic yaitu regresi linear berganda yang dapat dirumuskan:

$$
\mathbf{Y}=\mathbf{a}+\mathbf{b}_{1} \mathbf{X}_{1}+\mathbf{b}_{2} \mathbf{X}_{2}+\ldots \ldots \ldots \ldots . . . . b_{n} X_{n}+e
$$

Bila diformulasi matematis regresi liner berganda tersebut diaplikasikan dalam penelitian ini, maka akan diperoleh bentuk persamaan sebagai berikut:

Keterangan:

$$
\mathrm{Y}=\mathrm{a}+\mathrm{b} 1 \mathrm{X} 1+\mathrm{b} 2 \mathrm{X} 2+\mathrm{b} 3 \mathrm{X3}+\mathrm{e}
$$

$$
\begin{aligned}
\mathrm{Y} & =\text { Keputusan pembelian } \\
\mathrm{X}_{1} & =\text { Citra Perusahaan } \\
\mathrm{X}_{2} & =\text { Identitas Merek } \\
\mathrm{X}_{3} & =\text { Manfaat Merek } \\
\mathrm{a} & =\text { Konstanta / intercept } \\
\mathrm{b}_{1}-\mathrm{b}_{3} & =\text { Koefisien regresi } \\
\mathrm{e} & =\text { Kesalahan Penganggun (error). }
\end{aligned}
$$

\section{HASIL DAN PEMBAHASAN}


Berikut ini adalah hasil uji validitas dan reliabilitas atas item pernyataan yang terdapat dalam kuesioner penelitian terhadap variabel keunggulan asosiasi merek, kekuatan asosiasi merek, keunikan asosiasi merek dan keputusan konsumen. Adapun hasilnya disajikan dalam tabel 2 berikut:

Tabel.2

Hasil Uji Validitas dan Reabilitas

\begin{tabular}{|c|c|c|c|c|c|}
\hline Variabel & Item & $\begin{array}{c}\text { Total } \\
\text { Correlation }\end{array}$ & Ket & $\begin{array}{c}\text { Cronbach } \\
\text { Alpha }\end{array}$ & Ket \\
\hline $\begin{array}{c}\text { Keunggulan Asosiasi } \\
\text { Merek } \\
\text { (X1) }\end{array}$ & $\begin{array}{l}\mathrm{X} 1.1 \\
\mathrm{X} 1.2 \\
\mathrm{X} 1.3 \\
\mathrm{X} 1.4\end{array}$ & $\begin{array}{l}0,627 \\
0,566 \\
0,624 \\
0,438\end{array}$ & $\begin{array}{l}\text { Valid } \\
\text { Valid } \\
\text { Valid } \\
\text { Valid }\end{array}$ & 0,763 & Reliabel \\
\hline $\begin{array}{c}\text { Kekuatan Asosiasi } \\
\text { Merek } \\
\text { (X2) }\end{array}$ & $\begin{array}{l}\mathrm{X} 2.1 \\
\mathrm{X} 2.2 \\
\mathrm{X} 2.3 \\
\mathrm{X} 2.4 \\
\mathrm{X} 2.5 \\
\end{array}$ & $\begin{array}{l}0,533 \\
0,541 \\
0,636 \\
0,586 \\
0,410\end{array}$ & $\begin{array}{l}\text { Valid } \\
\text { Valid } \\
\text { Valid } \\
\text { Valid } \\
\text { Valid } \\
\end{array}$ & 0,767 & Reliabel \\
\hline $\begin{array}{c}\text { Keunikan Asosiasi } \\
\text { Merek } \\
\text { (X3) }\end{array}$ & $\begin{array}{l}\mathrm{X} 3.1 \\
\mathrm{X} 3.2 \\
\mathrm{X} 3.3 \\
\mathrm{X} 3.4\end{array}$ & $\begin{array}{l}0,647 \\
0,567 \\
0,412 \\
0,484\end{array}$ & $\begin{array}{l}\text { Valid } \\
\text { Valid } \\
\text { Valid } \\
\text { Valid }\end{array}$ & 0,737 & Reliabel \\
\hline $\begin{array}{c}\text { Keputusan Konsumen } \\
\text { (Y) }\end{array}$ & $\begin{array}{l}\text { Y.1 } \\
\text { Y.2 } \\
\text { Y.3 } \\
\text { Y.4 } \\
\text { Y.5 }\end{array}$ & $\begin{array}{l}0,311 \\
0,430 \\
0,318 \\
0,436 \\
0,410\end{array}$ & $\begin{array}{l}\text { Valid } \\
\text { Valid } \\
\text { Valid } \\
\text { Valid } \\
\text { Valid }\end{array}$ & 0,618 & Reliabel \\
\hline
\end{tabular}

Sumber: Data diolah Tahun 2018

Berdasarkan hasil uji validitas dan reliabilitas diperoleh bahwa seluruh variabel memiliki koefisien Cronbach Alpha (a) lebih besar dari 0,60 sehingga berdasarkan syarat minimum reliabilitas lebih besar dari 0,60 maka seluruh variabel yang digunakan reliabel dan dapat digunakan dalam penelitian. Sedangkan uji validitas terhadap seluruh variabel juga menunjukan nilai koefisien korelasi yang lebih besar dari 0,30 sehingga item pernyataan yang ada valid untuk digunakan.

\section{Hasil Uji Analisis Regresi Linear Berganda}

Penelitian ini menggunakan analisis regresi linear berganda dengan tujuan untuk menguji pengaruh Store Atmosphere terhadap kepuasan konsumen. Untuk lebih jelasnya hasil analisis regresi linear berganda dapat dilihat pada tabel 3 berikut:

\section{Tabel 3}

Hasil Uji Analisis Regresi Linear Berganda

\begin{tabular}{|c|c|c|c|c|c|}
\hline \multicolumn{6}{|c|}{ Dependen Variabel Y = Keputusan Konsumen } \\
\hline \multirow{2}{*}{$\begin{array}{l}\text { Variabel } \\
\text { Dependen }\end{array}$} & \multicolumn{2}{|c|}{$\begin{array}{l}\text { Unstandardized } \\
\text { Coefficients }\end{array}$} & \multirow{2}{*}{$\begin{array}{c}\text { Standardized } \\
\text { Coefficients }\end{array}$} & \multirow[t]{2}{*}{$\mathrm{T}$} & \multirow[t]{2}{*}{ Sig } \\
\hline & $\mathbf{B}$ & Std. Error & & & \\
\hline (Constant) & 0,517 & 0,357 & & 1.448 & 0,153 \\
\hline $\begin{array}{l}\text { Keunggulan } \\
\text { Asosiasi Merek }\end{array}$ & 0,130 & 0,060 & 0,151 & 2.173 & 0,034 \\
\hline $\begin{array}{l}\text { Kekuatan Asosiasi } \\
\text { Merek }\end{array}$ & 0,082 & 0,039 & 0,144 & 2.127 & 0,038 \\
\hline $\begin{array}{l}\text { Keunikan } \\
\text { Asosiasi Merek }\end{array}$ & 0,667 & 0,061 & 0,775 & 10.783 & 0,000 \\
\hline
\end{tabular}




\section{Multiple $=0,87^{\mathrm{a}} \quad$ Sig. $\mathrm{F}=\mathbf{0 , 0 0 0}$}

R Square $=\mathbf{0 , 7 5 1}$

Sumber: Data diolah Tahun 2018

Berdasarkan tabel 2 di atas, dapat di tulis dalam bentuk persamaan regresi linear berganda. Untuk lebih jelasnya bentuk persamaan tersebut dapat dilihat sebagai berikut:

$$
Y=0,517+0,130 X_{1}+0,082 X_{2}+0,667 X_{3}+e
$$

Berdasarkan penjabaran di atas menunjukkan bahwa, variabel independen yang dianalisis yaitu variabel $\left(\mathrm{X}_{1}, \mathrm{X}_{2}\right.$, dan $\left.\mathrm{X}_{3}\right)$ memberikan pengaruh posotif terhadap variabel dependen (Y), yaitu keputusan konsumen mobil Daihatsu Xenia membeli pada PT. Makassar Raya Motor Cabang palu. Untuk lebih jelasnya penjelasan bentuk persamaan tersebut dapat dilihat berikut ini:

1. Nilai Konstanta sebesar 0,517, artinya jika variabel (citra merek) bernilai 0, maka variabel dependen (keputusan konsumen membeli mobil Daihatsu Xenia pada PT. Makassar Raya Motor Cabang palu nilainya sebesar 0,517 . Setiap ada kenaikan pada variabel independen sebesar satu satuan maka akan meningkatkan variabel dependen sebesar nilai koefisiensi beta masing-masing variabel independen yang dikalikan dengan besarnya kenaikan yang terjadi.

2. Koefisien regresi dimensi keunggulan asosiasi merek sebesar 0,130, artinya jika keunggulan asosiasi merek naik satu satuan, maka keputusan konsumen membeli mobil Daihatsu Xenia pada PT. Makassar Raya Motor Cabang palu sebesar 0,130

3. Koefisien regresi dimensi kekuastan asosiasi merek sebesar 0,082, artinya jika Citra Pembuat naik satu satuan, maka keputusan konsumen membeli mobil Daihatsu Xenia pada PT. Makassar Raya Motor Cabang palu naik sebesar 0,082.

4. Koefisien regres idimensi keunikan asosiasi merek sebesar 0,667, artinya jika keunikan asosiasi merek naik satu satuan, maka keputusan konsumen membeli mobil Daihatsi Xenia pada PT. Makassar Raya Motor Cabang palu Palu naik sebesar 0,667.

Berdasarkan hipotesis pertama $\left(\mathrm{H}_{1}\right)$ adalah untuk mengetahui apakah Citra Merek yang terdiri dari keunggulan asosiasi merek, kekuatan asosiasi merek dan keunikan asosiasi merek secara serempak berpengaruh signifikan terhadap keputusan konsumen membeli mobil Daihatsu Xenia pada PT. Makassar Raya Motor Cabang palu. Untuk lebih jelasnya hasil dapat dilihat pada Tabel 4 berikut:

Tabel.4

Hasil Uji F (Simultan)

\begin{tabular}{|c|c|c|c|c|c|c|}
\hline \multicolumn{2}{|c|}{ Model } & Sum of Squares & Df & Mean Square & $\mathrm{F}$ & Sig. \\
\hline \multirow[t]{3}{*}{1} & Regression & 3.962 & 3 & 1.321 & 56.212 & $.000^{\mathrm{a}}$ \\
\hline & Residual & 1.316 & 56 & .023 & & \\
\hline & Total & 5.277 & 59 & & & \\
\hline
\end{tabular}

Sumber: Data diolah Tahun 2018

Berdasarkan tabel 3 di atas diperoleh Sig.F yaitu 0.000, artinya nilai tersebut lebih kecil dibandingkan dengan nilai yang disyaratkan yaitu $\alpha=0.05$ dengan tingkat kepercayaan 95\%. dengan demikian dapat dinyatakan bahwa secara simultan variabel Citra Merek yang terdiri dari keunggulan asosiasi merek, kekuatan asosiasi merek dan keunikan asosiasi merek secara serempak berpengaruh signifikan terhadap keputusan konsumen membeli mobil Daihatsu Xenia pada PT. Makassar Raya Motor Cabang palu dengan demikian hipotesis ini diterima.

Pengujian hipotesis secara parsial adalah untuk mengetahui apakah variabel Citra Merek yang terdiri dari keunggulan asosiasi merek, kekuatan asosiasi merek dan keunikan asosiasi merek secara serempak berpengaruh signifikan terhadap keputusan konsumen membeli mobil Daihatsu Xenia pada PT. Makassar Raya Motor Cabang palu. Adapun hasil pengujian secara parsial untuk setiap variabel independen terhadap variabel dependen dapat dilihat dari penjelasan berikut:

\section{Keunggulan Asosiasi Merek}

Berdasarkan hasil pengujian SPSS diperoleh hasil angka signifikan sebesar 0,034. Angka 0,034<0,05 oleh 
karena itu, hipotesis diterima. Hal ini berarti terdapat pengaruh variabel keunggulan asosiasi merek terhadap keputusan konsumen membeli mobil Daihatsu Xenia pada PT. Makassar Raya Motor Cabang palu

\section{Kekuatan Asosiasi Merek}

Berdasarkan hasil pengujian SPSS diperoleh hasil angka signifikan sebesar 0,038. Angka 0,038<0,05 oleh karena itu, hipotesis diterima. Hal ini berarti terdapat pengaruh variabel kekuatan asosiasi merek terhadap keputusan konsumen membeli mobil Daihatsu Xenia pada PT. Makassar Raya Motor Cabang palu.

\section{Keunikan Asosiasi Merek}

Berdasarkan hasil pengujian SPSS diperoleh hasil angka signifikan sebesar 0,000. Angka 0,000< 0,05 oleh karena itu, hipotesis diterima. Hal ini berarti terdapat pengaruh variabel keunikan asosiasi merek terhadap keputusan konsumen membeli mobil Daihatsu Xenia pada PT. Makassar Raya Motor Cabang palu.

Berdasarkan hasil pengujian serta analisis yang telah dilakukan pada penelitian ini membuktikan bahwa Store Atmosphere yang terdiri dari Exterior, General Interior, Store Layout, dan Interior Display secara simultan berpengaruh signifikan terhadap kepuasan konsumen pada Cafe Refresho di Kota Palu. Berdasarkan tabel rekapitulasi regresi linear berganda dapat dilihat pengaruh hasil uji determinasi Adjusted $R$ Square sebesar 0.684. Nilai tersebut dapat diartikan bahwa seluruh dimensi bebas yakni Exterior, General Interior, Store Layout, serta Interior Display mempunyai konstribusi secara bersama-sama sebesar $68.4 \%$ terhadap variabel terikat yaitu terhadap kepuausan konsumen pada Cafe Refresho di Kota Palu. Sedangkan sisanya $(100 \%-68.4 \%=31.6 \%)$, dipengaruhi oleh variabel lain yang tidak diteliti misalnya variabel kualitas layanan, dan lain-lain.

Hasil penelitian ini sejalan dengan penelitian sebelumnya yang dilakukan oleh Albagdadi (2017) yang menyatakan bahwa elemen suasana toko yang terdiri dari exterior, general interior, store layout, dan interior display secara simultan berpengaruh signifikan terhadap kepuasan pembelian konsumen berbelanja pada Swalayan Inti Makmur di Kota Palu.

\section{Dimensi Keunggulan Asosiasi Merek}

Berdasarkan hasil uji persial (uji t) yang dilakukan, menunjukkan hasil bahwa dimensi Keunggulan Asosia Merek berpengaruh signifikan terhadap keputusan Konsumen Membeli Mobil Daihatsu Xenia pada PT Makassar Raya Motor Cabang Palu dengan nilai signifikan. Alasan yang mendasari pengaruh dimensi keunggulan asosiasi merek terhadap keputusan konsumen membeli mobil Daihatsu Xenia yaitu memiliki citra merek yang baik dengan adanya kepercayaan dan loyalitas pelanggan yang setia dari pengguna Daihatsu Xenia yang selalu di pertahankan oleh PT. Makassar Raya Motor Cabang Palu kepada konsumenya. Serta kreadibilitas perusahaan PT. Makassar Raya Motor saat ini juga cukup meningkat dibanding pesaingnya, hal ini karena tanggapan masyarakat terhadap kemudahan dalam pengurususan berkas dan keamanan dalam bertransaksi. Daihatsu Xenia juga memiliki kulaitas model dan mempunyai fitur standar untuk smua tipe seperti Xenia Tipe R Sporty dan Xenia Delux sehingga memberikan kenyaman bagi pengendara mobil Xenia. Keputusan pembelian konsumen juga untuk memenuhi kebutuhan keluarga, aktifitas sosial, dan juga aktifitas usaha. Pilihan mobil seperti ini dengan ruang kabin yang luas dan nyaman sangat cocok untuk aktifitas-aktifitas tersebut.

\section{Dimensi Kekuatan Asosiasi Merek (X2).}

Berdasarkan hasil uji persial (uji t) terbukti bahawa dimensi kekuatan asosiasi merek berpengaruh signifikan terhadap keputusan Konsumen Membeli Mobil Daihatsu Xenia pada PT Makassar Raya Motor Cabang Palu denga nilai signifikan. Alasan yang mendasari pengaruh dimensi keunikan asosiasi merek terhadap membeli mobil Daihatsu Xenia pada PT Makassar Raya Motor Cabang Palu yaitu Daihatu Xenia memperkenalkan produknya melalui iklan yang ditawarkan melalui media cetak maupun media elektronik sehingga konsumen mengenal produk melalui periklanan yang dilakukan perusahaan. Logo produk Daihatsu Xenia sangat mudah dikenali dengan bentuknya yang unik, sehingga desain logonya sangat akrab di masyarakat. Desain eksterior Daihatsu Xenia juga menjadi salah satu faktor dalam melakukan keputusan pembelian, tampilan eksterior yang elegan dan selalu berinovasi membuat pelanggan lebih menyukai untuk memilih Daihatsu Xenia dibandingkan dengan mobil merek lain yang sekelasnya.

\section{Dimensi Keunikan Asosiasi Merek}

Berdasarkan hasil uji persial (uji t) terbukti bahwa dimensi Keunikan Asosiasi Merek berpengaruh singnifikan terhadap keputusan konsumen Membeli Mobil Daihatsu Xenia pada PT Makassar Raya Motor Cabang Palu dengan nilai signifikan. Alasan yang mendasari pengaruh dimensi Keunikan Asosiasi Merek terhadap keputusan konsumen membeli mobil Daihatsu Xenia pada PT Makassar Raya Motor Cabang Palu yaitu Daihatsu Xenia memiliki warna produk yang sangat bervariatif, variatif warna yang ditawarkan 
merupakan warna-warna yang cerah dan elegan, tentunya ini menjadi daya tarik tersendiri bagi konsumen yang cenderung memposisikan warna sebagi bentuk ekspresi.

\section{PENUTUP}

Berdasarkan hasil analisis dan pembahasan yang dilakukan mengenai Pengaruh Citra Merek Terhadap Keputusan Membeli Mobil Daihatsu Xenia Pada PT. Makassar Raya Motor Cabang Palu. Dapat disimpulkan sebagai berikut:

1. Citra Merek yang terdiri dari Keunggulan Asosiasi Merek, Kekuatan Asosiasi Merek, dan Keunikan Asosiasi Merek secara serempak berpengaruh signifikan terhadap keputusan pembelian mobil Daihatsu Xenia.

2. Dimensi Keunggulan Asosiasi Merek terbukti secara persial berpengaruh signifikan terhadap konsumen membeli mobil Daihatsu Xenia.

3. Dimensi Kekuatan Asosiasi Merek terbukti secara persial berpengaruh signifikan terhadap konsumen membeli mobil Daihatsu Xenia.

4. Dimensi Keunikan Asosiasi Merek terbukti secara persial berpengaruh signifikan terhadap konsumen membeli mobil Daihatsu Xenia.

Berdasarkan kesimpulan yang telah diuraikan sebelumnya, maka saran-saran yang tepat menyangkut kegunaan penelitian ini dapat diuraikan sebagai berikut:

1. Dengan ditemukannya signifikansi 3 variabel independen diatas secara serempak terhadap keputusan pembelian mobil Daihatsu Xenia pada PT. Makassar Raya Motor Cabang palu, perusahaan Daihatsu harus mempertahankan dan meningkatkan kualitas produk yang sudah terbentuk dengan baik agar dapat terus bertahan dalam persaingan. Dan kepada pihak perusahaan Daihatsu Xenia agar dapat lebih memperhatikan variabel Kekuatan Asosiasi Merek, khususnya indikator di kenal melalui iklan dengan pemsangan spanduk,poster, penyebaran brosur dan memperkenalkan produk melalui media surat kabar agar lebih di tingkatkan sehingga masyarakat lebih mudah mengetahui informasi tentag produk Daihatsu Xenia.

2. Penelitian skripsi ini penulis hanya membahas variabel Keunggulan Asosiasi Merek, Kekuatan Asosiasi Merek dan Keunikan Asosiasi Merek yang dijadikan faktor keputusan pembelian. Kepada peneliti selanjutnya diharpkan yang meneliti Citra Merek terhadap Keputusan Konsumen membeli Mobil Daihatsi Xenia Pada PT. Makassar Raya Motor Cabang Palu dapat menambahkan variabel-variabel lain diluar variabel dalam penelitian ini agar hasil didapatkan lebih maksimal.

\section{REFERENSI}

Desi 2017 Pengaruh Citra Merek Dan Pengetahuan Produk Terhadap Keputusan Pembelian Ulang Air Mineral Cleo Di Alfamidi Kota Palu

Ghozali, Imam. 2011 Aplikasi Analisis Multivariate dengan program SPSS. Badan Penerbit Universitas Diponegoro, Semarang.

Kotler, Philip \& Keller, Kevin. 2009 Manajemen Pemasaran : Edisi Ketiga Belas, Jilid 1, Jakarta: Erlangga.

Malhotra, Naresh K. 2006 Riset Pemasaran : Pendekatan Terapan jilid 2 . Jakarta: PT. Indeks.

Nickles, William. 2010 Pengantar Bisnis. Edisi Delapan. Buku 2. Jakarta..

Sugiyono. 2014 Metode Penelitian Pendidikan (Pendekatan Kuantitatif, Kualitatif dan R\&D). Bandung: Alfabeta.

Suyanto, Muhammad. 2008 Strategi Management. Yogyakarta: CV. Andi Offset 2008

PT. Makassar Raya Motor Cabang Palu 